THE DANCE OF FREEDOM 
NUMBER NINETEEN

Jack and Doris Smothers Series

in Texas History, Life, and Culture 


\section{The Dance of Freedom}

TEXAS AFRICAN AMERICANS

DURING RECONSTRUCTION

Barry A. Crouch

Edited by Larry Madaras

Foreword by Arnoldo de León

$\longrightarrow$ UNiversity OF TEXAS PRESS Austin 
“'Unmanacling' Texas Reconstruction: A Twenty-Year Perspective" originally appeared in Southwestern Historical Quarterly 93 (January I990): 275-302.

"Reconstructing Black Families: Perspectives from the Texas Freedmen's Bureau Records" (with Larry Madaras) originally appeared in Prologue: Journal of the National Archives I8 (Summer I986): I09-I22.

"Black Dreams and White Justice" originally appeared in Prologue: Journal of the National Archives 6 (Winter I974): 255-265.

"Seeking Equality: Houston Black Women during Reconstruction" originally appeared in Black Dixie: Afro-Texas History and Culture in Houston, ed. Howard Beeth and Cary D. Wintz (College Station: Texas A\&M University Press, I992): 54-73.

"A Spirit of Lawlessness: White Violence, Texas Blacks, I865-I868" originally appeared in Journal of Social History I 8 (December I984): 217-232.

"Crisis in Color: Racial Separation in Texas during Reconstruction” (with L. J. Schultz) originally appeared in Civil War History I6 (March I970): 37-49.

“"All the Vile Passions': The Texas Black Code of I 866" originally appeared in Southwestern Historical Quarterly 97 (July I993): I3-34.

"The Fetters of Justice: Black Texans and the Penitentiary during Reconstruction" originally appeared in Prologue: Journal of the National Archives 28 (Fall I996): I83-I93.

"Guardian of the Freedpeople: Texas Freedmen's Bureau Agents and the Black Community" originally appeared in Southern Studies 3 (Fall I992): I85-20 I.

"Hesitant Recognition: Texas Black Politicians, I 865-I900" originally appeared in East Texas Historical Journal 3 I (Spring I993): $4 \mathrm{I}-58$.

"Self-Determination and Local Black Leaders in Texas" originally appeared in Phylon 39 (December I978): 344-355.

"A Political Education: George T. Ruby and the Texas Freedmen's Bureau" originally appeared in Houston Review I 8, no. 2 (I996): I44-I56.
Copyright (C) 2007

by the University of Texas Press

All rights reserved

Printed in the United States of America

First edition, 2007

Requests for permission to reproduce material from this work should be sent to:

Permissions

University of Texas Press

P.O. Box 78 I9

Austin, TX 78713-78I9

www.utexas.edu/utpress/about/

bpermission.html

(2) The paper used in this book meets the minimum requirements of ANSI/NISO Z39.48I992 (RI997) (Permanence of Paper).

\section{LIBRARY OF CONGRESS}

CATALOGING-IN-PUBLICATION DATA

Crouch, Barry A., I94I-

The dance of freedom : Texas African

Americans during Reconstruction / Barry A. Crouch ; edited by Larry Madaras ; foreword by Arnoldo de León. - ist ed.

p. $\quad \mathrm{cm}$. - (Jack and Doris Smothers series in Texas history, life, and culture; no. I9) Includes bibliographical references and index.

ISBN-I3: 978-0-292-7I463-2 (cloth : alk. paper)

ISBN-IO: 0-292-7I463-7 (cloth : alk. paper) ISBN-I3: 978-O-292-7I487-8 (paper : alk. paper)

ISBN-IO: O-292-7I487-4 (paper : alk. paper) I. African Americans - Texas-HistoryI9th century. 2. African AmericansTexas - Social conditions - I9th century. 3. African Americans - Civil rights - TexasHistory-igth century. 4. African Americans - Texas - Politics and government - I9th century. 5. Freedmen-Texas-HistoryI9th century. 6. Reconstruction (U.S. history, I865-I877) - Texas. 7. Texas-Social conditions - I9th century. 8. RacismTexas-History- I9th century. 9. TexasRace relations - History - I9th century. Io. Texas Politics and government-I865I950. I. Madaras, Larry. II. Title.

EI 85.93.T4C75 2007

$976.4^{\prime} 00496073-\mathrm{dc} 22$

2006023207 